\title{
Technological exchanged natural radioactivity in vicinity of the Coal Burning Power Plant Kakanj, BiH
}

\author{
D. Samek, L. Saracevic, N. Gradascevic and A. Mihalj \\ Faculty of Veterinary Medicine, University Sarajevo, 71000 Sarajevo, \\ Bosnia and Herzegovina
}

\begin{abstract}
CBPP Kakanj is one of the most important Coal Burning Power Plants in Bosnia and Herzegovina (producing power of $450 \mathrm{MW}$, waste storage site of 5000000 tons). Mapping of the measured gamma-dose rate has been performed with the goal of identifying the hot spots in the area of $3 \times 3 \mathrm{~km}$ surrounding CBPP Kakanj, with special emphasis on the waste storage site $(1 \times 1 \mathrm{~km})$. Maximum measured of the gammadose rate surrounding CBPP Kakanj was $140 \mathrm{nGy} \mathrm{h}^{-1}$ and in the area of waste storage site $210 \mathrm{nGy} \mathrm{h}^{-1}$. Average levels of natural radionuclide in agricultural soil samples in vicinity of CBPP Kakanj are: for ${ }^{238} \mathrm{U}$ is $41 \pm 4 \mathrm{~Bq} \mathrm{~kg}^{-1},{ }^{232} \mathrm{Th}$ is $32 \pm 1 \mathrm{~Bq} \mathrm{~kg}^{-1},{ }^{226} \mathrm{Ra}$ is $27 \pm 2 \mathrm{~Bq} \mathrm{~kg}^{-1}$ and ${ }^{40} \mathrm{~K}$ is $486 \pm 9 \mathrm{~Bq} \mathrm{~kg}^{-1}$. Obtained results in soil-plant-animal products chain does not show significantly increased levels of natural radionuclides due to the fact that mentioned radionuclides, in general, have a low transfer factors in soilplant-animal products chain.
\end{abstract}

\section{INTRODUCTION}

The Basis Safety Standards for the health Protection of the General Public and Workers against the Dangers of Ionising Radiation [1] are laid down in a new Council Directive (96/29 EUROATOM dated on 13 May 1996 replace Directive 80/836 that is amended of Directive 84/476). The new Directive differs from the previous versions in the special provisions regarding exposure to the natural radiation sources that have been laid down (Title VII of the Directive). Such exposure was not explicitly within the scope of Standards hence the introduction of the new provisions may bring a significant change in national legislation. However, the Government of Bosnia and Herzegovina did not appoint the special authority for the implementation of Title VII of the new BBS. The all activities that were performing are results of our personal efforts and our wish to make some improvement in this field as well as the effort of one institution that is trying to do its job correctly.

The main goal of this paper is to explore radioactivity distribution in surroundings of CBPP Kakanj, as an outcome of using a coal in production process and its influence at radiation risk for population and environment.

\section{MATERIALS AND METHODS}

\subsection{Coal Burning Power Plant Kakanj}

CBPP Kakanj is placed in central part of Bosnia and Herzegovina near the town Kakanj (settlement size 46000 and settlements within distance less then $2 \mathrm{~km}$ ) and river Bosnia (distance less than $1 \mathrm{~km}$ ). It is one of the biggest Coal Burning Power Plants in Bosnia and Herzegovina with producing power of $450 \mathrm{MW}$, coal consumptions approximately of 1.2 millions tons per year, emission of ash 5500 tons per year (efficiency of filters is $99.3 \%$ ), production waste of 550000 tons per year (250000 waste are deposed at the waste disposal site (dry type) and 300000 tons was used for by-products) and waste storage site of 5000000 tons (living areas are at the distance approximately $3 \mathrm{~km}$ from waste storage site). CBPP Kakanj uses coals from eight different coal mines with following annual 
consumptions: Breza 272174, Vrtliste 301246, Haljinici 298682, Stara jama 314020, Zenica 143878, Drage-Tusnica 28424, Bila 53910 and Gracanica 65591 t/y.

\subsection{Sampling strategy}

Isodose maps, that cover the regions around CBPP Kakanj $(3 \mathrm{~km} \times 3 \mathrm{~km})$ and waste disposal region $(1 \mathrm{~km} \times 1 \mathrm{~km})$, were created. For estimating isodoses we were using Point Kriging Grid Method with Linear Variogram Model [2]. In accordance with predetermined grid, our measuring process includes 46 locations in CBPP Kakanj surroundings, and 29 locations in waste disposal site.

Samples of water, soil, grass, vegetables, meat and milk, used in gamma spectrometry analysis, were taken from the region covered with estimated isodoses. Soil samples were taken from 0 to $15 \mathrm{~cm}$ depth and with $5 \mathrm{~m} \times 5 \mathrm{~m}$ the size of the area (composite sample was measured by combining 3 individual samples). Sampling process was carried out at 8 permanently inhabited micro-locations, two times a year (early summer and late fall) for the period of three years (2004-2007). Samples of coal gamma spectrometry analysis were taken directly from mines ( 3 samples for each mine), twice a year (early summer and late fall) for the period of three years (2004-2007).

\subsection{Gamma spectrometry}

A stand-alone high-resolution spectroscopic system is used for the measurements of energy spectrum of the emitted gamma rays in the range between $50 \mathrm{keV}$ and $3000 \mathrm{keV}$. Measuring was performed on the background-protected coaxial detector p-type, vertical configuration "POP-TOP" model "GEM 30P4" relative efficiency $30 \%$ and resolution $1.85 \mathrm{keV}$ at $1.33 \mathrm{MeV}$ produced by EG\&G ORTEC.

The homogenized samples were transferred to 330 gram plastic containers (bottom diameter $8.5 \mathrm{~cm}$, top diameter $10 \mathrm{~cm}$, height $5 \mathrm{~cm}$ ) for gamma measurements and sealed for 12 weeks to ensure secular equilibrium between ${ }^{238} \mathrm{U}$ and ${ }^{234} \mathrm{Th}$, and radium and its radioactive progeny. The efficiency calibration of the detector was performed by following standard solutions: Ra-226 (Amersham), Uranium acetate (pa Merck), $\mathrm{KCl}$ (pa Merck) and Cs-137 (Amersham). The matrix for standard preparation was inert $\mathrm{CaCO}_{3}$ (pa powder) as well as distillate water. The measurements of the specific activities are determined with a level of confidence of $95 \%(2 \sigma)$.

\subsection{Dose rate measuring and radon detection}

Dose rates were measured at $1 \mathrm{~m}$ above ground with gamma dose rate meter LB-123 made by BERTHOLD, dose rate range $0.05 \mu \mathrm{Sv} \mathrm{h}^{-1}$ to $10 \mathrm{mSv} \mathrm{h}^{-1}$, energy range $30 \mathrm{keV}$ to $1.2 \mathrm{MeV}( \pm 30 \%$ relative to Cs-137) and resolution $0.01 \mu \mathrm{Sv} \mathrm{h}^{-1}$. Results are presented with statistical error of $10 \%$.

Alpha GUARD PQ-2200 (Genitron Instruments $\mathrm{GmbH}$ ) were used for radon detection.

\section{RESULTS}

Absorbed dose rates in vicinity of the CBPP Kakanj are showed in Figure 1. For estimating isodoses the value of the coefficient of multiple determinations was $\mathrm{R}^{2}=0.01698$, which shows the good agreement between measured and fitted data. Minimum value of the measured dose rate was $96 \mathrm{nGy} \mathrm{h}^{-1}$, while the maximum dose rate was $210 \mathrm{nGy} \mathrm{h}^{-1}$ (waste disposal storage site, Figure 2). Mean measure was $119.35 \mathrm{nGy} \mathrm{h}^{-1}$ with standard deviation of $17.41 \mathrm{nGy} \mathrm{h}^{-1}$ and it exceeds average background dose rate $\left(111 \mathrm{nGy} \mathrm{h}^{-1}\right)$ in Bosnia i Herzegovina for factor 1.08 only, while dose rate caused by cosmic radiation contributes $33 \%$, in average, in total measured dose rate [3].

Though, measured dose rates are not suited for Normal distribution (Kolmogorov-Smirnov $\left.\mathrm{d}=0.0986, \chi^{2}=12.6041, \mathrm{p}=0.0055\right)$, that implies dispersion and asymmetry of measured dose related to the expected value. 


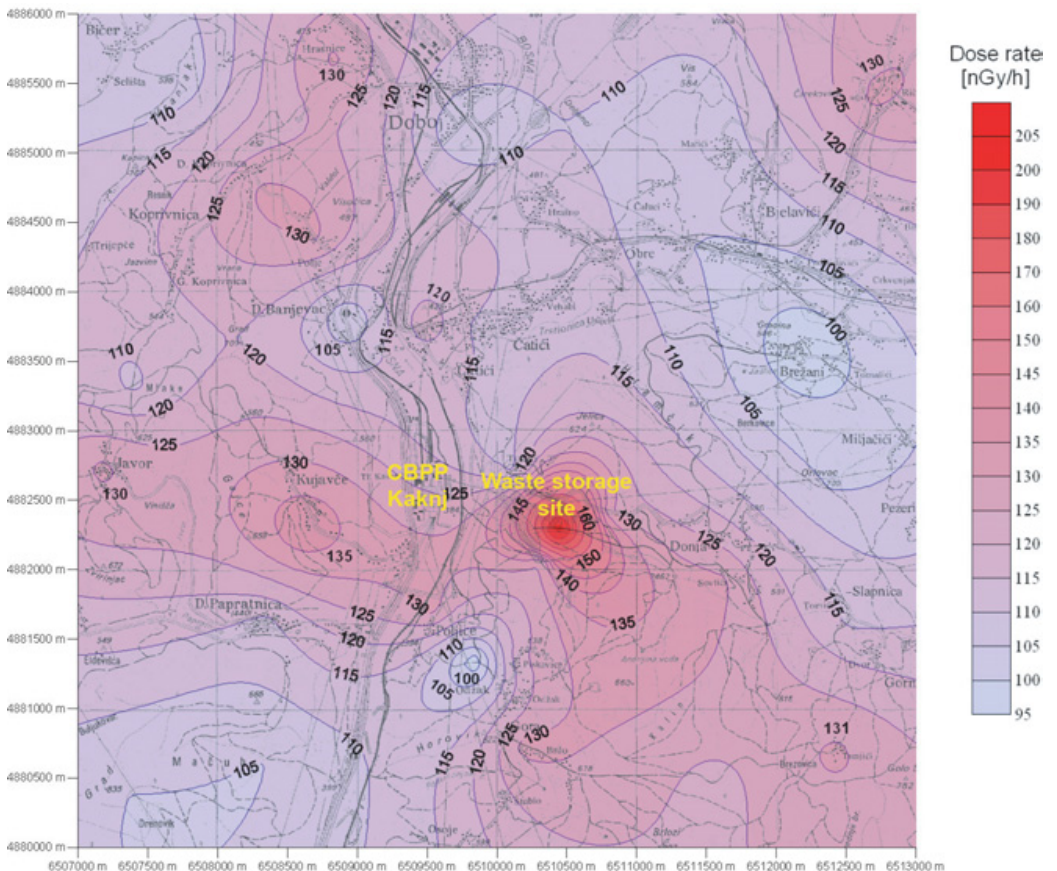

Figure 1. Isodose map of the CBPP Kakanj region.

Wind direction has a high influence on spreading the radioactivity. The points with slightly increased dose rate are placed along the main wind direction (north northwest - south southeast) (Figure 1). Also, points with higher altitude show lower values of absorbed dose rate.

Brown coal Drage-Tusnica shows the highest levels of uranium and radium among all coals used in CBPP Kakanj: $29 \pm 1$ for ${ }^{235} \mathrm{U}, 623 \pm 23 \mathrm{~Bq} \mathrm{~kg}^{-1}$ for ${ }^{238} \mathrm{U}, 1191 \pm 5 \mathrm{~Bq} \mathrm{~kg}^{-1}$ for ${ }^{226} \mathrm{Ra}, 27 \pm 2$ for ${ }^{232} \mathrm{Th}$ and $33 \pm 7$ for ${ }^{40} \mathrm{~K}$ (Table 1). Average activity in ash samples from plant are as follows: $6 \pm 1$ for ${ }^{235} \mathrm{U}, 129 \pm 11 \mathrm{~Bq} \mathrm{~kg}^{-1}$ for ${ }^{238} \mathrm{U}, 141 \pm 2 \mathrm{~Bq} \mathrm{~kg}^{-1}$ for ${ }^{226} \mathrm{Ra}^{2} 36 \pm 1$ for ${ }^{232} \mathrm{Th}$ and $360 \pm 10$ for ${ }^{40} \mathrm{~K}$, while the average activity in slag are as follows: $4 \pm 1$ for ${ }^{235} \mathrm{U}, 91 \pm 9 \mathrm{~Bq} \mathrm{~kg}^{-1}$ for ${ }^{238} \mathrm{U}, 95 \pm 2 \mathrm{~Bq} \mathrm{~kg}^{-1}$ for ${ }^{226} \mathrm{Ra}, 32 \pm 2$ for ${ }^{232} \mathrm{Th}$ and $240 \pm 8$ for ${ }^{40} \mathrm{~K}$. Average activity in ash and slag samples from waste disposal site are as follows: $4 \pm 1$ for ${ }^{235} \mathrm{U}, 85 \pm 11 \mathrm{~Bq} \mathrm{~kg}^{-1}$ for ${ }^{238} \mathrm{U}, 96 \pm 2 \mathrm{~Bq} \mathrm{~kg}^{-1}$ for ${ }^{226} \mathrm{Ra}, 32 \pm 2$ for ${ }^{232} \mathrm{Th}$ and $240 \pm 8$ for ${ }^{40} \mathrm{~K}$.

Table 2 shows specific activity in water of Slapnica brook - Kakanj. Obtained results show that waste disposal site has the impact on the water stream despite the fact that obtained values do not point

Table 1. Average specific activity of coals used in CBPP Kakanj.

\begin{tabular}{|c|c|c|c|c|c|}
\hline \multirow{2}{*}{ Coal mine } & \multicolumn{5}{|c|}{ Activity $(\mathrm{Bq} / \mathrm{kg})$} \\
\cline { 2 - 6 } & $\mathrm{U}-235$ & $\mathrm{U}-238$ & Th-232 & Ra-226 & $\mathrm{K}-40$ \\
\hline Breza & $1.70 \pm 0.21$ & $36.98 \pm 4.61$ & $9.57 \pm 0.66$ & $26.23 \pm 1.33$ & $66.98 \pm 4.15$ \\
\hline Vrtliste & $1.82 \pm 0.31$ & $39.58 \pm 6.63$ & $21.78 \pm 1.00$ & $42.05 \pm 1.24$ & $199.09 \pm 6.84$ \\
\hline Haljinici & $2.54 \pm 0.31$ & $55.08 \pm 6.64$ & $17.69 \pm 0.81$ & $46.62 \pm 1.27$ & $129.57 \pm 5.82$ \\
\hline Stara jama & $1.55 \pm 0.22$ & $33.58 \pm 4.77$ & $11.03 \pm 0.66$ & $29.23 \pm 0.11$ & $75.37 \pm 4.43$ \\
\hline Zenica & $1.08 \pm 0.18$ & $23.36 \pm 3.84$ & $5.61 \pm 0.47$ & $23.44 \pm 0.71$ & $40.68 \pm 3.39$ \\
\hline Tusnica & $28.68 \pm 1.07$ & $623.03 \pm 23.32$ & $26.67 \pm 1.86$ & $1191.34 \pm 4.83$ & $33.92 \pm 7.20$ \\
\hline Bila & $2.20 \pm 0.29$ & $47.89 \pm 6.33$ & $17.28 \pm 0.92$ & $46.71 \pm 1.15$ & $199.41 \pm 6.73$ \\
\hline Gracanica & $7.62 \pm 0.86$ & $165.41 \pm 10.07$ & $4.25 \pm 0.63$ & $145.14 \pm 1.74$ & $16.92 \pm 1.86$ \\
\hline
\end{tabular}




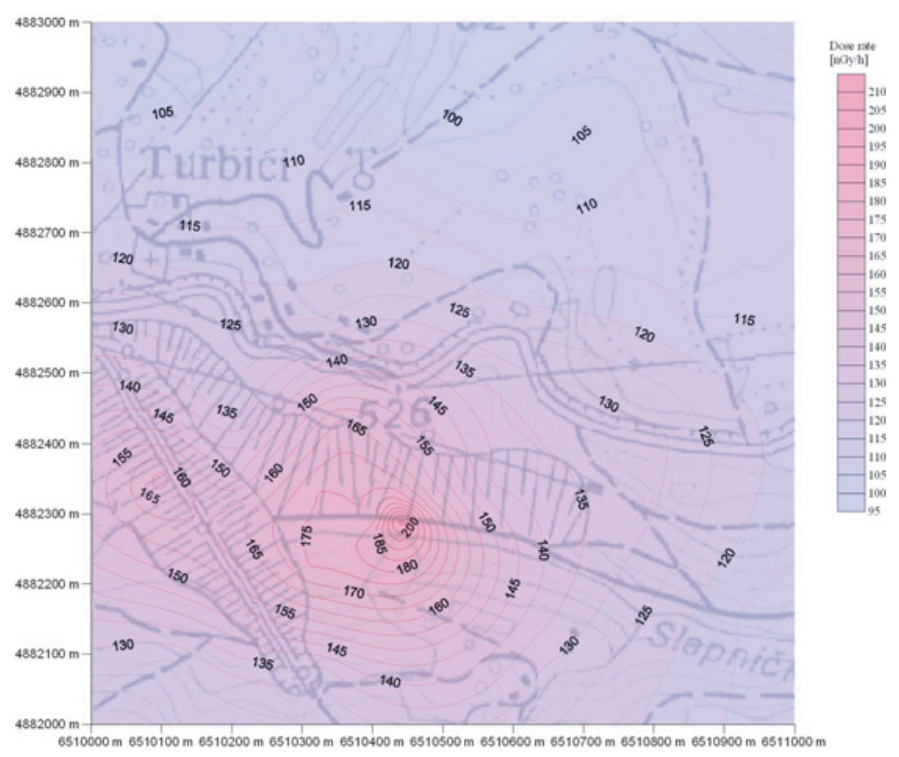

Figure 2. Isodose map of the waste disposal storage region.

Table 2. Specific activity in water of Slapnica brook - Kakanj.

\begin{tabular}{|c|c|c|}
\hline \multirow{2}{*}{ Radionuclide } & \multicolumn{2}{|c|}{ Activity (mBq/L) } \\
\cline { 2 - 3 } & Point upstream of the waste & $\begin{array}{c}\text { Point downstream of the } \\
\text { waste }\end{array}$ \\
\hline U-238 & $29.7 \pm 5.8$ & $59.7 \pm 16.6$ \\
\hline Th-232 & $7.6 \pm 0.7$ & $16.7 \pm 4.1$ \\
\hline Ra-226 & $4.1 \pm 0.3$ & $13.05 \pm 1.43$ \\
\hline K-40 & $82.1 \pm 3.6$ & $385.7 \pm 16.6$ \\
\hline
\end{tabular}

on the significant contamination of water. That could be partly explained by the fact that brook is sealed along the part which flow below the waste storage site.

Generally, obtained results for radon concentration in waste and the air at the waste storage site are low that does not point to increased levels of radon caused by the wastes (Table 3).

Average values for basic physio-chemical parameters of agricultural soil samples in vicinity of CBPP Kakanj were: $\mathrm{Ph} 7.90$, humus $3.9 \%$, humidity $2.26 \%$, minerals $87.35 \%$ and organic matter $10.39 \%$, with predominantly clay base, while the average activity in agricultural soil are as follows: $41 \pm 4$ for ${ }^{238} \mathrm{U}, 27 \pm 2 \mathrm{~Bq} \mathrm{~kg}^{-1}$ for ${ }^{226} \mathrm{Ra}, 32 \pm 2$ for ${ }^{232} \mathrm{Th}$ and $486 \pm 9$ for ${ }^{40} \mathrm{~K}$. As you can notice, there is no significant difference between measured and average levels of radionuclides in the soil for territory of Bosnia and Herzegovina [3].

Compared to the average values in the world [4], obtained results in soil-plant-animal products chain does not show significantly increased levels of natural radionuclides, because mentioned radionuclides, in general, have a low transfer factor for soil-plant-animal products system (Table 4).

It seams that observed natural radionuclides show a low bioavailability that cause the low levels of radionuclides in observed agricultural and animal samples. The highest value of radium and uranium activity, was found in hay and chicken meat $\left({ }^{238} \mathrm{U} 0.30 \pm 0.07 \mathrm{~Bq} \mathrm{~kg}^{-1},{ }^{226} \mathrm{Ra} 0.70 \pm 0.05 \mathrm{~Bq} \mathrm{~kg}^{-1}\right.$ for hay and ${ }^{238} \mathrm{U} 0.10 \pm 0.03 \mathrm{~Bq} \mathrm{~kg}^{-1},{ }^{226} \mathrm{Ra} 0.52 \pm 0.08 \mathrm{~Bq} \mathrm{~kg}^{-1}$ for chicken meat). Probably it was caused by the concentration of radionuclide during the drying of hay and by specific eating habits of the animal (picking food and eating from soil surface). Average dose taken through ingestion of mentioned agricultural products, meat and animal products is $0.253 \mathrm{mSv}$ a year. 
Table 3. Radon activity concentration in waste and air at the waste storage site.

\begin{tabular}{|c|c|c|c|}
\hline \multirow{2}{*}{ POINT } & $\begin{array}{c}\text { Rn in waste } \\
(\text { Depth } 80 \mathrm{~cm})\end{array}$ & $\begin{array}{c}\text { Rn in air } \\
(1 \mathrm{~m} \text { above the ground })\end{array}$ & Coordinates \\
\hline \multirow{3}{*}{ Waste storage 1 } & $190 \mathrm{~Bq} / \mathrm{m}^{3}$ & $8.3 \mathrm{~Bq} / \mathrm{m}^{3}$ & $\mathrm{E} 6510387$ \\
\cline { 2 - 4 } & $51 \mathrm{mWL}$ & $2 \mathrm{mWL}$ & $\mathrm{N} 4882306$ \\
\hline \multirow{3}{*}{ Waste storage 2 } & $460 \mathrm{~Bq} / \mathrm{m}^{3}$ & $10.3 \mathrm{~Bq} / \mathrm{m}^{3}$ & $\mathrm{E} 6510330$ \\
\cline { 2 - 4 } & $124 \mathrm{mWL}$ & $3 \mathrm{mWL}$ & $\mathrm{N} 4882324$ \\
\hline \multirow{3}{*}{ Waste storage 3 } & $514 \mathrm{~Bq} / \mathrm{m}^{3}$ & $8.3 \mathrm{~Bq} / \mathrm{m}^{3}$ & $\mathrm{E} 6510151$ \\
\cline { 2 - 4 } & $139 \mathrm{mWl}$ & $2 \mathrm{mWL}$ & $\mathrm{N} 4882345$ \\
\hline \multirow{3}{*}{ Waste storage 4 } & $1610 \mathrm{~Bq} / \mathrm{m}^{3}$ & $6.9 \mathrm{~Bq} / \mathrm{m}^{3}$ & $\mathrm{E} 6510151$ \\
\cline { 2 - 4 } & $435 \mathrm{mWL}$ & $2 \mathrm{mWL}$ & $\mathrm{N} 4882395$ \\
\hline \multirow{2}{*}{ Waste storage 5 } & $1700 \mathrm{~Bq} / \mathrm{m}^{3}$ & $9.0 \mathrm{~Bq} / \mathrm{m}^{3}$ & $\mathrm{E} 6510312$ \\
\cline { 2 - 4 } & $459 \mathrm{mWL}$ & $2 \mathrm{mWL}$ & $\mathrm{N} 4882282$ \\
\hline
\end{tabular}

Table 4. Average specific activity of plants, agricultural and animal products $\left(\mathrm{Bq} \mathrm{kg}^{-1}\right)$.

\begin{tabular}{|c|c|c|c|}
\hline Sample & U-238 & Ra-226 & K-40 \\
\hline Grass & $0.100 \pm 0.040$ & $0.230 \pm 0.100$ & $175.30 \pm 12.20$ \\
\hline Hay & $0.300 \pm 0.070$ & $0.700 \pm 0.050$ & $513.80 \pm 19.20$ \\
\hline Corn Stalk & $0.090 \pm 0.030$ & $0.170 \pm 0.050$ & $160.80 \pm 11.30$ \\
\hline Corn & $0.100 \pm 0.040$ & $0.240 \pm 0.080$ & $279.10 \pm 12.10$ \\
\hline Bean & $0.010 \pm 0.004$ & $0.060 \pm 0.010$ & $329.20 \pm 14.20$ \\
\hline Potato & $0.020 \pm 0.007$ & $0.030 \pm 0.009$ & $178.90 \pm 12.90$ \\
\hline Turnip & $0.060 \pm 0.013$ & $0.09 \pm 0.014$ & $85.10 \pm 7.80$ \\
\hline Cow meat & $0.020 \pm 0.006$ & $0.030 \pm 0.008$ & $96.70 \pm 9.80$ \\
\hline Cow milk & $0.010 \pm 0.006$ & $0.025 \pm 0.008$ & $47.68 \pm 5.80$ \\
\hline Cow cheese & $0.025 \pm 0.009$ & $0.053 \pm 0.010$ & $42.81 \pm 6.70$ \\
\hline Chicken meat & $0.100 \pm 0.030$ & $0.520 \pm 0.080$ & $136.50 \pm 11.40$ \\
\hline
\end{tabular}

\section{CONCLUSIONS}

Brown coals Tusnica-Drage show the highest levels of uranium and radium between all coals used in CBPP Kakanj.

Obtained results do not show significantly increased levels of natural radionuclides due to the fact that mentioned radionuclides, in general, have a low transfer factors in soil-plant-animal products system. It seams that observed natural radionuclides show a low bioavailability which cause the low levels of observed radionuclides in agricultural and animal samples.

Furthermore, the measured dosage for the population surrounding CBPP Kakanj does not point towards significant radioactivity risk.

\section{Acknowledgments}

This study was financially supported by $6^{\text {th }}$ European Framework Programme, Contract No INCO-CT-2004509214, project title "Assessment of the environmental risk for use of radioactively contaminated industrial tailings".

\section{References}

[1] International Atomic Energy Agency (IAEA), International Basic Safety Standards for Protection againist Ionizing Radiation and for Safety of Radiation Sources (International Atomic Energy Agency, Safety Series No. 115, Vienna, 1996).

[2] N.A.C. Cressie, Mathematical Geology 22, 239-252 (1990). 
[3] D. Samek, L. Saracevic, A. Mihalj and N. Gradascevic, "Estimation of the External Gamma Dose Rate from Natural Radionuclides on the Territory of Bosnia and Herzegovina", Proceedings of the $5^{\text {th }}$ Symposium of the Croatian Radiation Protection Association, Stubicke Toplice, 2003, edited by I.C. Bronic, S. Miljanic and B. Obelic (HDZZ-CRPA, Zagreb, 2003) p. 296-301.

[4] United Nations Scientific Committee on the Effects of Atomic Radiation (UNSCEAR), Sources, Effects and Risk of Ionizing Radiation (Report to the General Assembly, with Scientific Annexes, United Nations, New York, 2000). 